\title{
Isolation and characterization of a mammalian orthoreovirus type 3 in a fecal sample of wild boar in Japan
}

\author{
Wenjing Zhang ${ }^{1}$, Michiyo Kataoka ${ }^{2}$, Yen Doan $^{3}$, Toru $\mathrm{Oi}^{4}$, Tetsuya Furuya ${ }^{5}$, mami oba ${ }^{5}$, \\ Tetsuya Mizutani ${ }^{5}$, Tomoichiro Oka ${ }^{1}$, Tiancheng $\mathrm{Li}^{1}$, and Makato Nagai ${ }^{6}$ \\ ${ }^{1}$ Kokuritsu Kansensho Kenkyujo Murayama Chosha \\ ${ }^{2}$ National Institute of Infectious Diseases \\ ${ }^{3}$ Tokyo Medical and Dental University \\ ${ }^{4}$ Ishikawa Prefectural University \\ ${ }^{5}$ Tokyo University of Agriculture and Technology \\ ${ }^{6}$ Azabu University
}

November 30, 2020

\begin{abstract}
Mammalian orthoreoviruses (MRVs) have been identified in various mammalian species, including humans, bats, and pigs. However, MRV isolation and complete genome sequences from wild boars have not yet been reported. In this study, we isolated, sequenced, and analyzed an MRV from a free-living wild boar in Japan using a porcine sapelovirus-resistant cell line N1380. The complete and empty virus particles were obtained from the N1380 cell culture supernatants, and complete genome sequences were obtained from complete virus particles. Sequence analyses revealed that the isolated MRV, named TY-14, was classified as MRV3 and had a close genetic relationship with lion in a Japanese zoo MRV2 (L2, L3, and M3 genes) and human MRV2 from Japan (S2 gene). Phylogenetic analyses showed that TY-14 clustered only with bat MRVs in the M1 gene, while TY-14 formed a cluster with several animal MRVs in the M2 and S3 genes, and independently branched in the L1, S1, and S4 genes, suggesting a genetic relationship with other unknown origins. Recombination events were identified in the M2 gene. These results suggest that TY-14 was generated by reassortment and recombination events involving MRVs circulating in Japan, bats, and other unknown origins.
\end{abstract}

\section{Hosted file}

Zhang_et_al._Orthoreovirus_TY14_20201130_Re-submit.pdf available at https://authorea. com/users/379942/articles/496127-isolation-and-characterization-of-a-mammalian-

orthoreovirus-type-3-in-a-fecal-sample-of-wild-boar-in-japan 

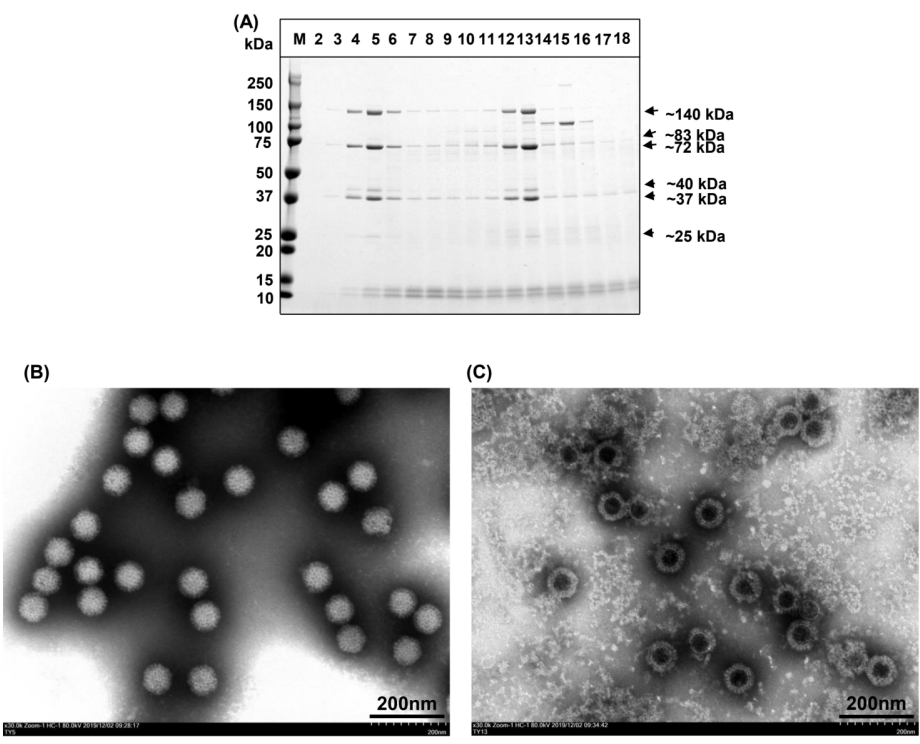

Fig. 1. Zhang et al. 


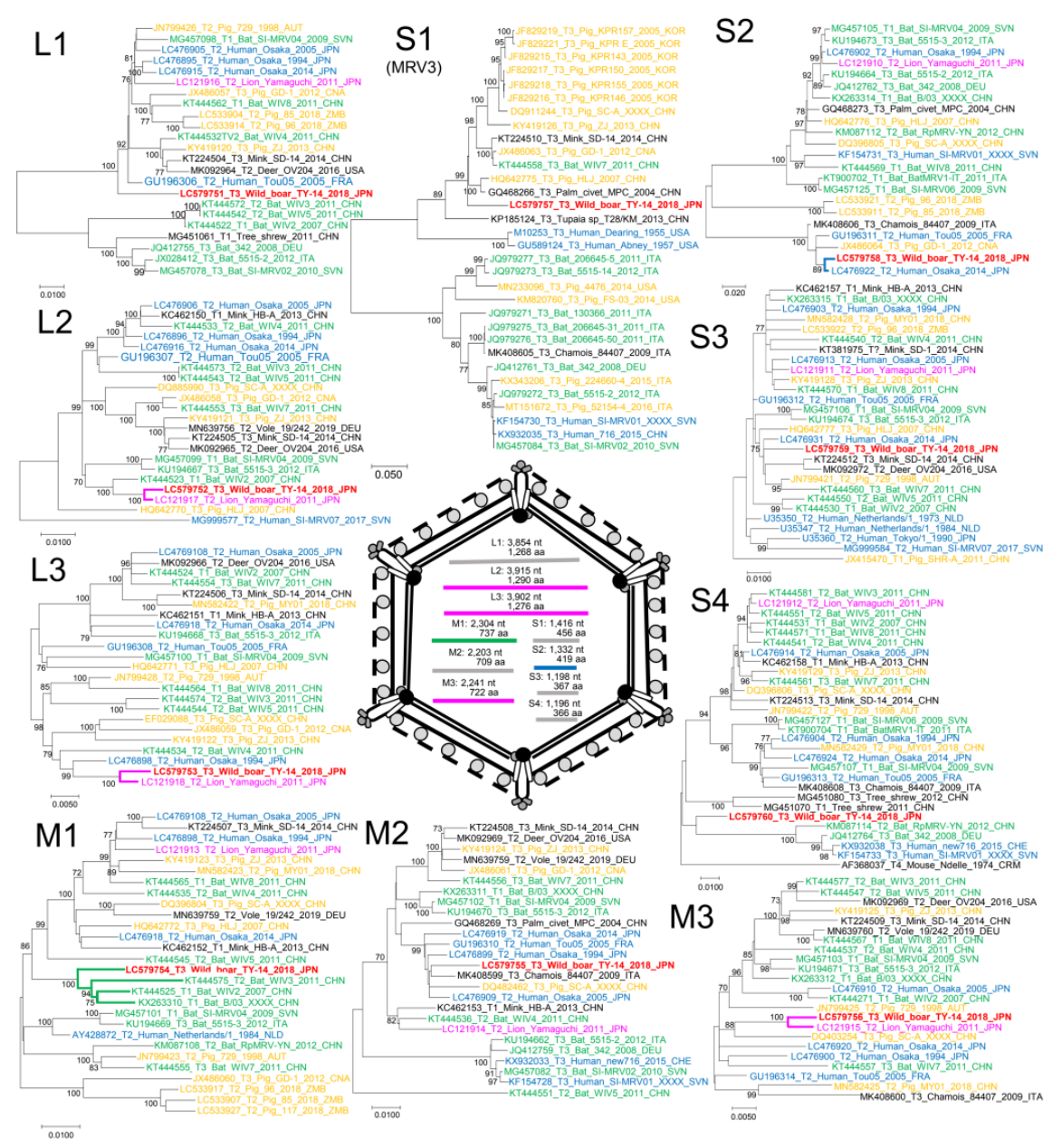

Fig. 2. Zhang et al.

\section{Hosted file}

Fig. 3. Zhang et al. TY14 Reassortant analysis 2020.11.23.pptx available at https:// authorea.com/users/379942/articles/496127-isolation-and-characterization-of-a-mammalianorthoreovirus-type-3-in-a-fecal-sample-of-wild-boar-in-japan

\section{Hosted file}

Fig. 4. Zhang et al. TY14 Recommbination analysis 2020.11.14.pptx available at https: //authorea.com/users/379942/articles/496127-isolation-and-characterization-of-amammalian-orthoreovirus-type-3-in-a-fecal-sample-of-wild-boar-in-japan

\section{Hosted file}

Table1 Zhang et al. TY-14 piarwise identities 2020.11.15.xlsx available at https:// authorea.com/users/379942/articles/496127-isolation-and-characterization-of-a-mammalian- 
orthoreovirus-type-3-in-a-fecal-sample-of-wild-boar-in-japan 